\title{
TOMATOES USED BY INDUSTRIES HAVE TECHNOLOGICAL QUALITY FOR FRESH CONSUMPTION ${ }^{1}$
}

\author{
DAIANNA PEREIRA COSTA ${ }^{2 *}$, JULIANA NASCIMENTO SILVA ${ }^{2}$, SILWANNA PEREIRA COSTA $^{3}$, ABADIA DOS \\ REIS NASCIMENTO ${ }^{2}$
}

\begin{abstract}
The production of tomato (Solanum lycopersicum L.) for fresh consumption must overcome a challenge: the high production cost. The use of cultivars with determinate growth habit is an alternative to reduce costs. Thus, the objective this work was to evaluate the acceptability of tomato fruits from cultivars with determinate growth habit for fresh consumption. Seeds of 10 hybrids and one variety were grown in open field, arranged in six randomized block design, and tested for sensorial acceptability. The analyses were carried out using 50 not-trained consumers, considering their visual and sensorial preferences by affective methods and purchase intention. The hybrid Thaise grown with and without staking and the hybrid Gabrielle grown with staking had higher visual preference by the consumers, with frequency of $24 \%, 18 \%$, and $22 \%$, respectively, in the first position; and the hybrid Dominador showed higher frequency (18\%) in the second and third positions; these hybrids had purchase intention above $80 \%$. All hybrids and varieties had significant difference in the mean test at $p \leq 0.05$. The highest means found for Carrara, HM7885, Santa Cruz Kada, Asti, N901, Dominador, and Equatorial (appearance); Asti and N901 (color), Asti, Dominador, and Equatorial (aroma), and Santa Cruz Kada, Asti, Dominador, and Equatorial (flavor). Asti, Gabrielle (grown without staking), HM7885, and Equatorial had purchase intention above of 50\%. The hybrids Ap533, Portinari, and Thaise grown without staking showed acceptability index lower than $70 \%$. Plants with determinate growth habit produce fruits with acceptable visual and sensorial qualities for fresh consumption.
\end{abstract}

Keywords: Solanum lycopersicum. Determinate growth habit. Acceptability. Consumer.

\section{O TOMATE USADO NA INDÚSTRIA POSSUI QUALIDADE TECNOLÓGICA PARA CONSUMO IN NATURA}

RESUMO - O tomateiro (Solanum lycopersicum L.) destinado ao consumo in natura, possui como desafio a ser superado o custo de produção elevado. Uma alternativa, é utilizar cultivares com hábito de crescimento determinado. O objetivo da pesquisa foi detectar a aceitabilidade ao tomate com hábito de crescimento determinado para o consumo in natura. Sementes de 10 híbridos e uma variedade foram conduzidas em campo aberto, dispostas em seis blocos casualizados e usadas para os testes sensoriais. As análises foram realizadas por 50 consumidores não treinados, os quais avaliaram a preferência visual, sensorial por métodos afetivos e intenção de compra. Os híbridos Thaise cultivado rasteiro e tutorado, e Gabrielle tutorado, apresentaram 24; 18 e $22 \%$ de frequência respectivamente, lideraram a primeira posição da preferência visual, em segundo e terceiro o híbrido dominador com $18 \%$, estes tiveram intenção de compra, acima de $80 \%$. Todos os híbridos e variedades tiveram diferença significativa no teste de média com $\mathrm{p} \leq 0,05$. As maiores médias foram: aparência com Carrara, HM7885, Santa Cruz Kada, Asti, N901, Dominador e Equatorial. Cor com Asti e N901, aroma com Asti, Dominador e Equatorial, e sabor, Santa Cruz Kada, Asti, Dominador e Equatorial. A intenção de compra acima de 50\% foi para Asti, Gabrielle* (cultivado rasteiro), HM7885 e Equatorial, apenas os híbridos Ap533, Portinari e Thaise cultivado rasteiro obtiveram índice de aceitabilidade inferior a 70\%. Assim, é possível inferir que plantas com hábito de crescimento determinado produzem frutos com qualidade visual e sensorial para o consumo in natura.

Palavra-chave: Solanum lycopersicum. Hábito de crescimento determinado. Aceitação. Consumidor.

\footnotetext{
"Corresponding author

${ }^{1}$ Received for publication in $08 / 06 / 2019$; accepted in $05 / 15 / 2020$

Paper extracted from the doctoral thesis of the first author.

${ }^{2}$ Department of Horticulture, Universidade Federal de Goiás, Goiânia, GO, Brazil; daiannaagronoma@gmail.com - ORCID: 0000-00034382-6665, agronomia125@gmail.com - ORCID: 0000-0001-9533-6030, abadiadosreis@ufg.br-ORCID: 0000-0003-3952-5878.

${ }^{3}$ Department of Medicine, Universidade Estadual do Maranhão, Caxias, MA, Brazil; silwanna.costa@hotmail.com - ORCID: 0000-00016845-6512.
} 


\section{INTRODUCTION}

Tomato (Solanum lycopersicum L.) is a plant species that belongs to the Solanaceae family. It stands out economically and nutritionally among vegetables, and is the second most consumed vegetable in the world, after potato. Tomato fruits have several antioxidants compounds, such as vitamin E, ascorbic acid, carotenoids, flavonoids, and phenolic compounds (BORGUINI; TORRES, 2009; PERVEEN et. al., 2015; SIDDIQUI; AYALAZAVALA; DHUA, 2015).

Tomato crops contribute significantly to the gross domestic product (GDP) of Brazil; however, their prices remain above the production cost over most part of the year since 2013 (DELEO et al., 2020). The Brazilian tomato production in 2018 was $4,110,242 \mathrm{Mg}$, and the planted area was 57,134 ha, resulting in a yield of $71,940 \mathrm{~kg} \mathrm{ha}^{-1}$, but the planted area decreased 8.4\% in 2019 (FAOSTAT, 2020).

Despite the expressive Brazilian production, the high production cost and logistic difficulties increase the sustainability of this crop. Tomato production intended for fresh consumption has higher costs with specialized labor, and its cultural practices require more time. According to the Institute for Agriculture Support of Goiás, and the Center for Advanced Studies in Economy, tomato production costs in the Central-West and Southeast regions of Brazil reached R\$ 104,918.2 for fresh consumption and R\$21,469.66 for industry in 2018 and 2019 (IFAG, 2020; DELEO, 2020). The lower production cost of industrial tomato is due to the choice of producers for this crop type.

The use of hybrids with determinate growth habit is an alternative to decrease tomato production cost for fresh consumption. However, these hybrids must have enough fruit quality to compete with those grown with staking, which usually have indeterminate growth habit.

Fruit quality is related to sensorial aspects, such as appearance, aroma, flavor, and texture, which are dependent on physical, physical-chemical, and chemical characteristics. Quality can be defined as the set of characteristics that differ individual components of a same product by their significance in the determination of acceptability by the consumer (CHITARRA; CHITARRA, 2005).

According to Kader et al. (1977), the unsatisfaction of consumers regarding the tomato fruit quality and price is noted since the 1970s. Thus, alternative production systems that improve fruit price and quality are needed. Thus, evaluating the acceptability of tomato fruits by consumers is necessary to plan the production of tomato from plants with determinate growth habit for fresh consumption, and this can be evaluated using sensorial affective tests.

Affective tests assist in the decision making of consumers by accessing their actual and potential opinion about a product; they are mainly applied to maintain the quality, optimize products or processes, and develop new products (DUTCOSKY, 2013; LAWLESS; HEYMANN, 2010).

Therefore, studies are needed to evaluate whether the quality and sensorial attributes of fruits from hybrids with determinate growth habit, originally used for processing, are acceptable by consumers as an alternative for fresh consumption, since they can make the tomato production more sustainable and due to a lower production cost.

In this context, the objective of this work was to evaluate the acceptability of tomato fruits from cultivars with determinate growth habit for fresh consumption.

\section{MATERIAL AND METHODS}

The experiment was conducted in Goiânia, GO, Brazil $\left(16^{\circ} 35^{\prime} 12^{\prime \prime} \mathrm{S}, 49^{\circ} 21^{\prime} 14^{\prime \prime} \mathrm{W}\right.$, and $730 \mathrm{~m}$ of altitude) from April to September 2016. The soil of the area was classified as Typic Hapludox of clayey texture (486 $\mathrm{g} \mathrm{kg}^{-1}$ sand, $100 \mathrm{~g} \mathrm{~kg}^{-1}$ silt, and $414 \mathrm{~g} \mathrm{~kg}$ ${ }^{-1}$ clay). The climate of the region is Aw, tropical hot and rainy, with a rainy season from October to March, and a dry season from April to September.

Seeds of 10 tomato hybrids and one tomato variety were sown in polyethylene trays containing a sterile substrate; the seedlings were produced and maintained in the nursery up to the transplant to the field, after 39 days. The seedlings were transplanted to pits in raised beds in an area with soil tillage, fertilization, and irrigation. Soil fertilization was carried out based on the chemical analysis. Planting fertilization consisted of incorporating $\mathrm{CO}\left(\mathrm{NH}_{2}\right)$, $\mathrm{P}_{2} \mathrm{O}_{5}$ and $\mathrm{KNO}_{3}$ into the soil. Fertigation consisted of weekly application of $\mathrm{Ca}$ and $\mathrm{Bo}$ after the beginning of the flowering stage. A drip irrigation system was used for irrigation, with emitters spaced $0.30 \mathrm{~m}$ apart and daily applications with flow varying from 3 to $30 \mathrm{~mm}$. Mulching with a black and white plastic was used. The plants were grown in an open field with spacing of 0.5 meters between plants and $2 \mathrm{~m}$ between rows, arranged in six randomized blocks; the plots consisted of 10 plants. The tomato hybrids and the tomato variety were grown with and without staking (Table 1). 
Table 1. Tomato hybrids and a tomato variety (Santa Cruz Kada) grown in an open field. Goiânia, GO, Brazil.

\begin{tabular}{llll}
\hline Hybrids & Growth habit & Growth system & Company \\
\hline Ap 533 & Determinate & without staking & Seminis \\
HM7885 & Determinate & without staking & Agristar-topseed \\
N901 & Determinate & without staking & Nunhemes \\
Gabrielle & Determinate & without staking & Hazera seeds \\
Gabrielle & Determinate & with staking & Hazera seeds \\
Thaise & Determinate & without staking & Feltrin \\
Thaise & Determinate & with staking & Feltrin \\
Equatorial & Determinate & with staking & Agrocinco \\
Asti & Indeterminate & with staking & Hortivale \\
Carrara & Indeterminate & with staking & Hortivale \\
Dominador & Indeterminate & with staking & Agristar-topseed \\
Santa Cruz Kada & Indeterminate & with staking & Feltrin \\
BRS Portinari & Indeterminate & with staking & Agrocinco \\
\hline
\end{tabular}

The hybrids with staking were tied with plastic bands; hybrids with indeterminate growth habit were grown with two stems, and those with determinate growth habit were grown with all stems.

Four plants of each hybrid and variety of each block were selected for the sensorial tests. Seven red ripe fruits were randomly chosen and harvested from these plants in the morning period; all fruits were cleaned with neutral detergent and tap water.

The project was submitted to the Ethical Council of the Federal University of Goiás for evaluation, following the Normative no. 1723105 of the Brazilian National Health Council (National Research Ethical Commission - CONEP), and the requirements established by the Resolution CNS $466 / 12$ and their amendments (BRASIL, 2012). The analyses were carried out using 50 not-trained consumers of both the sexes, with age between 18 and 59 years $96.92 \%$ with age between 18 and 30, and $3.08 \%$ with age between 32 to $59 ; 46.92 \%$ women and $53.08 \%$ men. They were high school or college graduates that were approached at the Federal University of Goiás. The evaluations of the fruits of the different tomato hybrids and the tomato variety were performed in an environment under uniform illumination and room temperature. All consumers reported to consume fresh tomato fruits at least once a week, and $26.92 \%$ reported to consume them with a frequency of seven times a week.

The consumers were exposed to 13 groups of fruits for the visual test of preference and sensorial analysis by affective methods. The tomato hybrids and the tomato variety, and the consumers were divided into three groups: the first tested four cultivars (three hybrids and one variety), the second evaluated other four hybrids, and the third group evaluated five hybrids; the tomato hybrids and the tomato variety were divided into groups to avoid confusions in the evaluations.

Three whole red ripe fruits of each cultivar (12 hybrids and one variety) were packed in polyethylene trays and covered with $0.01-\mathrm{mm}$ PVC film for the visual preference test. The trays were arranged in a bench and, then, each consumer, individually, placed the fruits by increasing order of preference, answering whether they would purchase the fruit.

The diameter, weight, and firmness of the three fruits of each treatment used in the visual preference test were determined. The fruit diameter was measured using a digital caliper, and the results were expressed in millimeters ( $\mathrm{mm})$; the fruit weight was measured using a digital balance and the results were expressed in grams $(\mathrm{g})$. The fruit firmness was measured using a leveler the fruits were placed on the device table and their firmness was determined by the ratio between the leveler glass board weight and the area formed by compressing the fruit, and the results were expressed in $\mathrm{N} \mathrm{cm}^{-2}$ (CALBO, 2011).

Fruits samples were kept under refrigeration and evaluated in the same day, after the evaluation of the consumers, and subjected to sensorial analysis by affective methods. The fruits were evaluated for soluble solid, titratable acidity, and vitamin C contents. Soluble solid and titratable acidity contents were determined according to the methodology described by Moretti et al. (1998) and AOAC (2012). Vitamin $\mathrm{C}$ was evaluated in $10 \mathrm{~g}$ of ground tomato diluted into $50 \mathrm{~mL}$ of distilled water, adding $1 \mathrm{~mL}$ of $1 \%$ starch solution and, then, $1 \mathrm{~mL}$ of $10 \%$ potassium iodate with $10 \mathrm{~mL}$ of $20 \%$ sulfuric acid. The solution was titrated with potassium iodate $0.002 \mathrm{M}$ up to the brown color turning point; the result was obtained by the equation: vitamin $C(\mathrm{mg}$ $\%)=100 \times$ iodate volume spent in the titration $\times$ $0.8806 / \mathrm{g}$ of sample, and the result was expressed as percentage of vitamin $\mathrm{C}$, following the methodology described by IAL (2008).

The fruits were cleaned with neutral detergent and tap water, chopped into small pieces, and offered to the consumers, in 50-mL disposable plastic cups for the sensorial analysis by affective methods; water was offered as a drink between tastings.

The not-trained consumers evaluated the tomatoes for appearance, color, aroma, and flavor through a 5-grade hedonic scale, in which $9=$ highly liked, $8=$ liked, $7=$ moderately liked, $6=$ slightly liked, $5=$ indifferent, $4=$ slightly not liked, $3=$ 
moderately not liked, 2 = not liked, $1=$ highly not liked (MORAES, 1988; NASSU, 2007). Subsequently, the consumers evaluated the hybrids for purchase intention with a 5-grade scale, in which $5=$ would always purchase, $4=$ would often purchase, 3 = would occasionally purchase, $2=$ would seldom purchase, $1=$ would never purchase.

The data of sensorial analyses were subjected to analysis of variance, Scott-Knott test at 5\% significance level, acceptability index according to Dutcosky (2013), agreement among the consumers for the evaluated attributes, and frequency test.

\section{RESULTS AND DISCUSSION}

The biometric characteristics distinguished the fruits into oblong (transversal diameter smaller than the longitudinal) and round (transversal diameter larger than the longitudinal). The hybrids Ap533, Carrara, Equatorial, and Gabrielle grown with and without staking, and the HM7885, Santa Cruz Kada, Asti, and N901 were classified as oblong. Among the oblong fruits, those from the hybrids AP533, HM788, N901, Santa Cruz Kada, and Equatorial were the smallest, with transversal diameter smaller than $50 \mathrm{~mm}$; the other oblong fruits presented transversal diameter larger than $50 \mathrm{~mm}$ and lower than $60 \mathrm{~mm}$ and were characterized as medium, according the Ordinance MAARA no. 553/95 (BRASIL, 1995) and the Attachment XVII of the Ordinance SARC no. 085/02 of the Brazilian Ministry of Agriculture, Livestock and Food Supply (MAPA) (BRASIL, 2002).
The hybrids Portinari and Thaise grown with and without staking and the hybrid Dominador showed round fruits, presenting transversal diameter smaller than the longitudinal; and the hybrid Portinari was the smallest, with transversal diameter smaller than $65 \mathrm{~mm}$. The standard classification used in the present study followed the current legislation (Ordinance MAARA no. 553/95 - BRASIL, 1995; and the Attachment XVII of the Ordinance SARC no. 085/02 of the MAPA - BRASIL, 2002), which establish that fresh tomatoes are classified by groups, subgroups, classes or gauge, type, or selection degree.

The hybrid Thaise grown with and without staking and the hybrid Gabrielle grown with staking had higher visual preference by the consumers, with frequency of $24 \%, 18 \%$, and $22 \%$, respectively, in the first position. The hybrid Dominador showed higher frequency $(18 \%)$ in the second and third positions. The hybrids Portinari and Carrara had higher frequency in the fifth position, with $20 \%$ and $14 \%$, respectively; Asti and Gabrielle grown without staking had higher frequency in the seventh position, with $18 \%$ and $16 \%$ respectively; Equatorial had higher frequency in the eighth and ninth positions, with $18 \%$; N901 had higher frequency in the tenth position, with $26 \%$; the variety Santa Cruz Kada had higher frequency in the eleventh position, with $30 \%$; AP533 and HM7885 had higher frequency in the twelfth position, with $26 \%$ and $32 \%$, respectively; and Carrara and HM7885 had higher frequency in the in the thirteenth position, with $14 \%$ and $32 \%$, respectively (Figure 1).

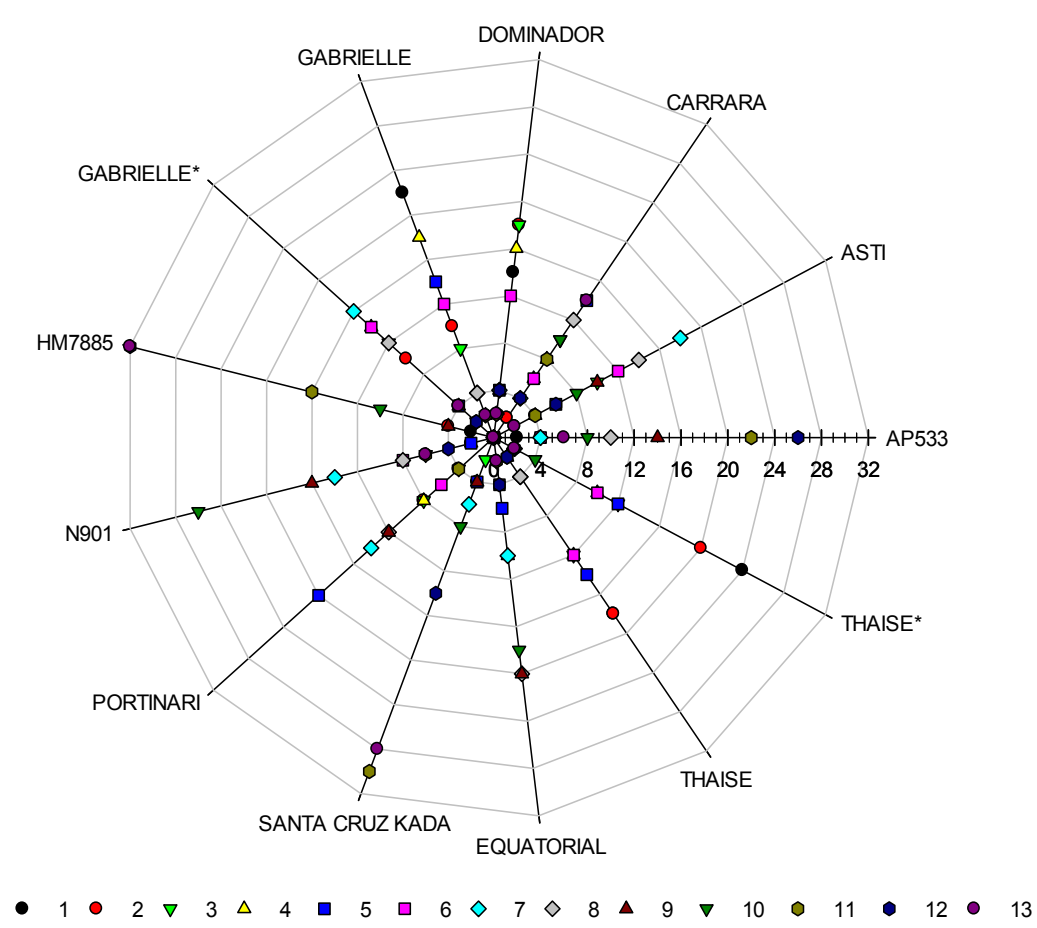

Figure 1. Visual analysis of tomato fruits by 50 consumers in order of preference. 
The preference of consumer is affected by size, color, form, pulp firmness, and peel characteristics and general appearance of the fruit. These characteristics determine the fruit visual quality. The largest fruits with oblong or round shape were the ones preferred by the consumers. The smallest fruits were rejected; considering the visual evaluation and purchase intention, more than $50 \%$ of the consumers reported that they would not purchase fruits of the cultivars AP533, HM7885, N901, and Santa Cruz Kada fruits for fresh consumption. The not acceptability a product in the consumer market is a consequence of the divergence between the consumer needs and expectations regarding sensorial properties of the product (LAWLESS; HEYMANN, 2010).

The highest acceptability in the visual evaluation (above 80\%) was found for fruits from plants of the cultivars Gabrielle and Thaise grown with and without staking, and those from plants of the hybrid Dominador, which has indeterminate growth habit. This denotes that tomatoes from plants with determinate growth habit are accepted by the consumers when visually evaluated (Figure 2).



Figure 2. Purchase intention (\%) of tomato fruits by 50 not-trained consumers. Goiânia, GO, Brazil.

All cultivars were acceptable for fresh consumption based on their titratable acidity, solid soluble, vitamin $\mathrm{C}$, and soluble solid to titratable acidity ratio (SS/TA), as found by Alvarenga et al.
(2013). The general means of these attributes were $32.44 \%$ for vitamin C, $0.27 \%$ for titratable acidity, 4.15 for ${ }^{\circ}$ Brix, and 16.74 for SS/TA (Table 2).

Table 2. Vitamin C (VC, \%), titratable acidity (TA, \% citric acid), soluble solid (SS, ${ }^{\circ}$ Brix), and SS to TA ratio (SS/TA) of tomato hybrids and a tomato variety. Goiânia, GO, Brazil.

\begin{tabular}{lllll}
\hline Treatment & VC & TA & SS & SS/TA \\
\hline AP533 & 35.03 & 0.27 & 3.90 & 14.63 \\
Carrara & 20.59 & 0.16 & 4.30 & 27.48 \\
Gabrielle & 13.83 & 0.22 & 3.80 & 16.90 \\
HM7885 & 35.40 & 0.20 & 3.60 & 17.75 \\
Santa Cruz & 37.17 & 0.19 & 4.50 & 23.27 \\
Asti & 41.89 & 0.28 & 4.50 & 16.34 \\
N901 & 42.83 & 0.29 & 4.40 & 15.13 \\
Portinari & 26.79 & 0.23 & 4.60 & 20.31 \\
Thaise* & 34.05 & 0.49 & 3.90 & 7.96 \\
Dominador & 32.29 & 0.23 & 3.90 & 16.72 \\
Gabrielle* & 33.63 & 0.31 & 4.10 & 13.43 \\
Equatorial & 35.03 & 0.29 & 4.60 & 15.80 \\
Thaise & 33.20 & 0.32 & 3.80 & 11.92 \\
\hline Mean & 32.44 & 0.27 & 4.15 & 16.74 \\
\hline
\end{tabular}

*grown without staking. 
$\mathrm{SS} / \mathrm{TA}$ can be used to indicate fruit quality because fruits with high SS/TA tend to have a mild flavor due to their sugar and acid combination, whereas those with low SS/TA tend to have an acid flavor (FERREIRA et al., 2010).

Tomato fruits have good flavor when presenting SS/TA higher than 10 (KADER et al., 1978). The fruits of all cultivars presented SS/TA higher than 10, except Thaise when grown without staking, generating a pleasant smell and flavor. Flavor is affected by the combination of smells and tactile sensations that are dependent on the balance between sugars, organic acids, volatile compounds, and free amino acids (OMS-OLIU, 2011).

The fruits of all cultivars received grade 9 (highly liked) at least once for the appearance, color, aroma, and flavor. The standard deviation and coefficient of variation were, in general, higher for the characteristic flavor (Table 3).

The mean test at $p \leq 0.05$ showed significant differences between cultivars for fruit appearance, aroma, color, and flavor. The highest means for fruit appearance were found for Carrara, HM, Santa Cruz Kada, Asti, N901, Dominador, and Equatorial; Asti, N901, and Equatorial were preferred for color; and Asti, Dominador, and Equatorial were preferred for aroma (Table 3).

The highest means for fruit flavor were found for fruits of plants of the cultivars Santa Cruz Kada, Asti, Dominador, and Equatorial. At least one hybrid with determinate growth habit and grown without staking was preferred for appearance, aroma, color, and flavor, showing that these hybrids are alternative cultivars for tomato production for fresh consumption based on their sensorial attributes (Table 3).

Table 3. Standard deviation (SD) and means (M) of grades attributed to appearance, color, aroma, and flavor of tomato fruits evaluated by 50 not-trained consumers. Goiânia, GO, Brazil.

\begin{tabular}{lccccc}
\hline \multicolumn{1}{c}{ Treatment } & Grade & Appearance & Color & Aroma & Flavor \\
\hline Ap533 & SD $-\mathrm{M}$ & $1.61-6.54 \mathrm{~B}$ & $1.79-6.18 \mathrm{~B}$ & $1.79-5.92 \mathrm{~B}$ & $2.32-5.5 \mathrm{~A}$ \\
Carrara & SD $-\mathrm{M}$ & $1.41-7.02 \mathrm{C}$ & $1.53-6.88 \mathrm{C}$ & $2.04-5.82 \mathrm{~B}$ & $2.65-5.98 \mathrm{~B}$ \\
Gabrielle & SD $-\mathrm{M}$ & $1.86-6.78 \mathrm{~B}$ & $1.81-6.88 \mathrm{C}$ & $1.47-6.6 \mathrm{D}$ & $1.95-6.24 \mathrm{~B}$ \\
Hm7885 & SD $-\mathrm{M}$ & $1.78-7.12 \mathrm{C}$ & $1.38-7.36 \mathrm{D}$ & $1.39-6.7 \mathrm{D}$ & $1.86-6.16 \mathrm{~B}$ \\
Santa Cruz Kada & $\mathrm{SD}-\mathrm{M}$ & $1.18-7.3 \mathrm{C}$ & $1.41-7.38 \mathrm{D}$ & $1.52-6.94 \mathrm{D}$ & $1.49-7.4 \mathrm{C}$ \\
Asti & $\mathrm{SD}-\mathrm{M}$ & $1.41-7.6 \mathrm{C}$ & $1.11-7.78 \mathrm{E}$ & $1.42-7.54 \mathrm{E}$ & $1.39-7.54 \mathrm{C}$ \\
N901 & $\mathrm{SD}-\mathrm{M}$ & $1.25-7.42 \mathrm{C}$ & $1.38-7.66 \mathrm{E}$ & $1.83-6.72 \mathrm{D}$ & $2.05-6.42 \mathrm{~B}$ \\
Portinari & $\mathrm{SD}-\mathrm{M}$ & $1.91-5.96 \mathrm{~A}$ & $1.43-5.72 \mathrm{~A}$ & $1.97-5.32 \mathrm{~A}$ & $2.58-5 \mathrm{~A}$ \\
Thaise* & $\mathrm{SD}-\mathrm{M}$ & $1.85-6.46 \mathrm{~B}$ & $1.80-6.14 \mathrm{~B}$ & $1.53-6.42 \mathrm{C}$ & $1.94-5.8 \mathrm{~B}$ \\
Dominador & $\mathrm{SD}-\mathrm{M}$ & $1.37-7.38 \mathrm{C}$ & $1.52-7.22 \mathrm{D}$ & $1.41-7.06 \mathrm{E}$ & $1.90-6.84 \mathrm{C}$ \\
Gabrielle* & $\mathrm{SD}-\mathrm{M}$ & $1.39-6.9 \mathrm{~B}$ & $1.81-6.8 \mathrm{C}$ & $1.45-6.26 \mathrm{C}$ & $1.78-6.16 \mathrm{~B}$ \\
Equatorial & $\mathrm{SD}-\mathrm{M}$ & $1.07-7.54 \mathrm{C}$ & $1.02-7.88 \mathrm{E}$ & $1.47-7.12 \mathrm{E}$ & $1.32-7.26 \mathrm{C}$ \\
Thaise & $\mathrm{SD}-\mathrm{M}$ & $1.61-6.88 \mathrm{~B}$ & $1.75-6.72 \mathrm{C}$ & $1.94-6.2 \mathrm{C}$ & $2.21-5.92 \mathrm{~B}$ \\
\hline CV $\%$ \% & & 17.74 & 15.01 & 18.32 & 26.40 \\
\hline
\end{tabular}

Means followed by the same letter in the columns are not different by the Scott-Knott test $(p \leq 0.05)$. ${ }^{*}$ grown without staking.

The attributes appearance, color, and aroma were graded by the consumers as 8 (liked) with acceptability higher than $50 \%$ for all cultivars, denoting the fruits quality and acceptability by consumers regarding these attributes for all cultivars (Figures 3, 4 and 5). Sensorial tests are a quality control method for products; in the case of fruits, they have been a decisive technique to assess the preferences of consumers (SOUZA et al., 2013).

Only the hybrid Portinari had no high acceptability index for fruit flavor; the other cultivars had grades of 6 to 9 (liked) in the hedonic scale (Figure 6).

The sensorial analysis of fruits used by the industry is a strategic tool to popularize tomatoes that are not traditionally consumed by consumers as fresh fruits. However, to confirm that these fruits can be accepted by the consumer market, they are expected to have acceptability index of at least $70 \%$ (DUTCOSKY, 2013). Acceptability index lower than $70 \%$ was found for the hybrids Portinari, for all attributes; Ap533, for color, aroma, and flavor; and Thaise, for aroma and flavor (without staking), which were consequently not accepted. The other hybrids (Carrara, Gabrielle, HM7885, Asti, N901, Dominador, Gabrielle - without staking, Equatorial, and Thaise) and the variety Santa Cruz Kada had general mean acceptability index higher than $70 \%$, and were consequently accepted for fresh consumption, denoting that such fruits are an alternative of purchase. 


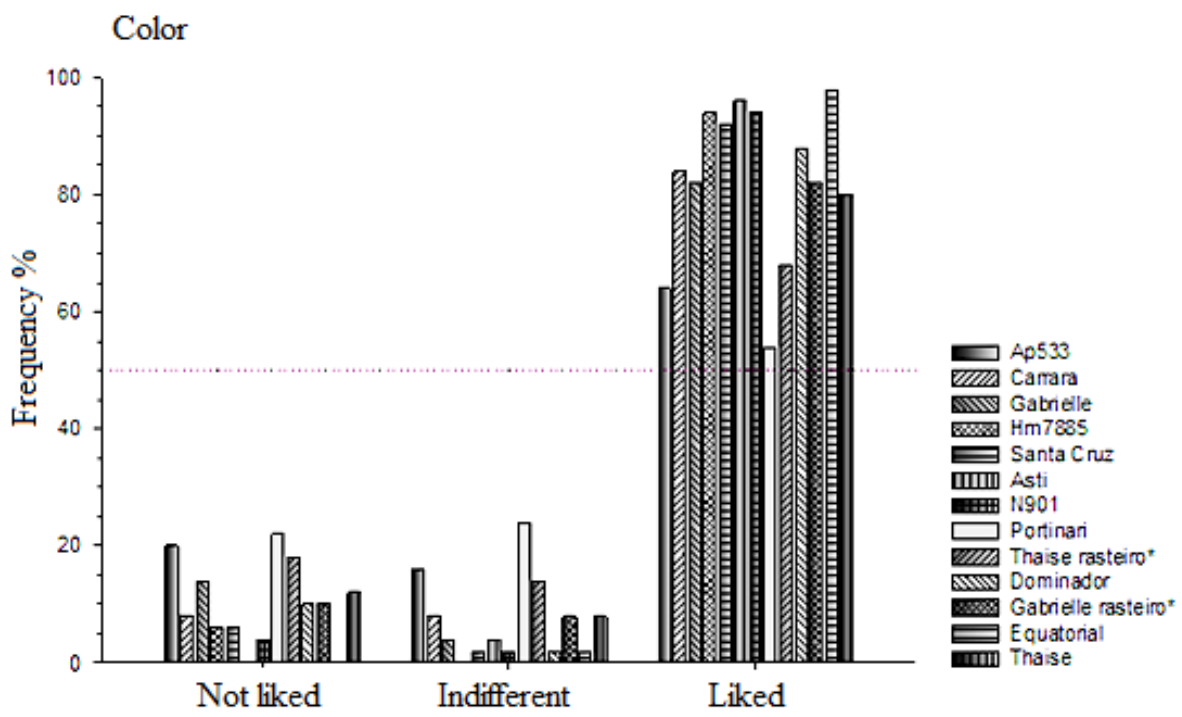

Figure 3. Acceptability index of tomato fruits by consumers considering their color. Goiânia, GO, Brazil.

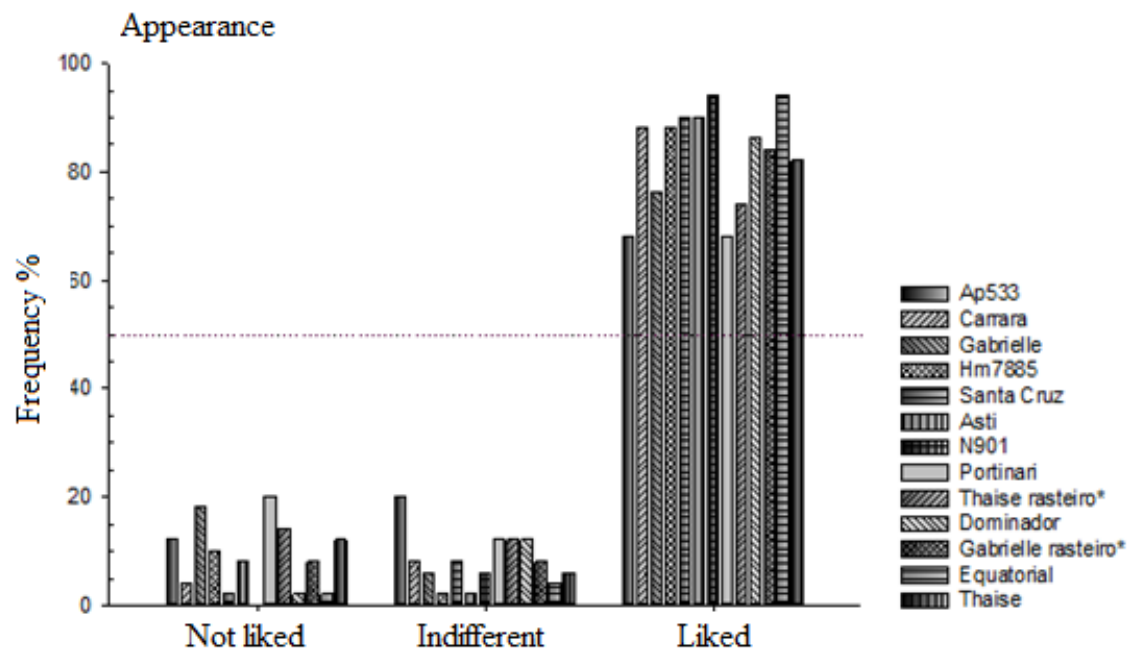

Figure 4. Acceptability index of tomato fruits by consumers considering their appearance. Goiânia, GO, Brazil.

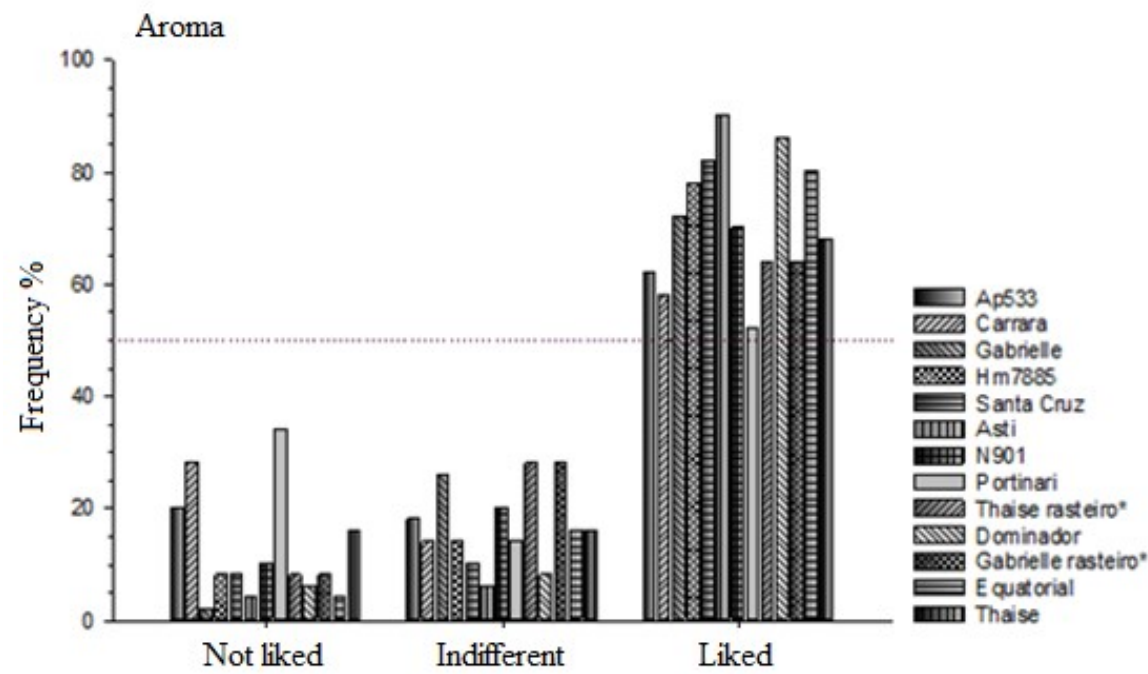

Figure 5. Acceptability index of tomato fruits by consumers considering their aroma. Goiânia, GO, Brazil. 


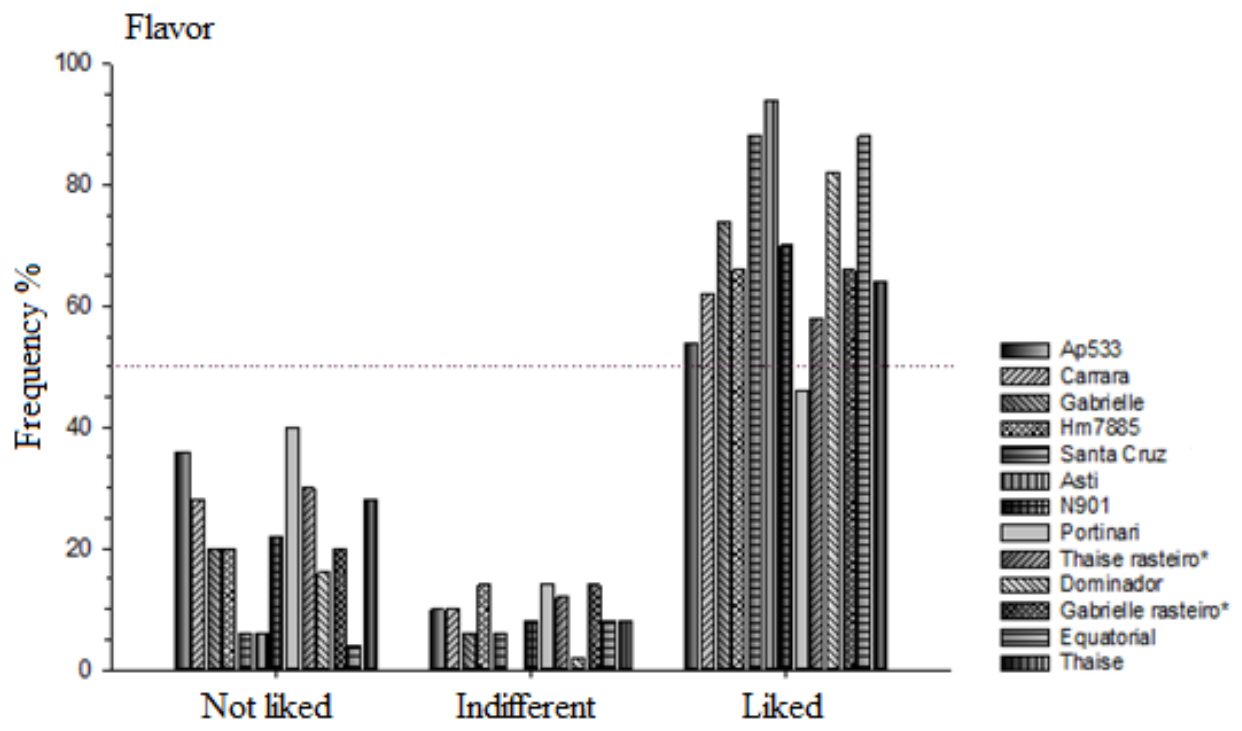

Figure 6. Acceptability index of tomato fruits by consumers considering their flavor. Goiânia, GO, Brazil.

Some studies focused on marketing have pointed out that sensorial analysis assists in the consumers decision based on the most relevant sensorial attributes (KEMP; HOLLOWOOD; HORT, 2009; MEILGAARD; CIVILLE; CARR, 2016; LAWLESS; HEYMANN, 2010). Appearance at the time of purchase tended to be the first attribute pointed out by consumers, when the it is not possible to evaluate the flavor. The acceptability of consumers, considering the fruit appearance, was above $70 \%$ for all the hybrids and the tomato variety, according to the acceptability index, except for Portinari (Table 4).

Table 4. Acceptability index for tomato fruits based on grades attributed by 50 not-trained consumers. Goiânia, GO, Brazil.

\begin{tabular}{lccccc}
\hline \multirow{2}{*}{ Treatment } & \multicolumn{3}{c}{ Acceptability Index (\%) } & Mean \\
\cline { 2 - 5 } & Appearance & Color & Aroma & Flavor & 67.06 \\
Ap533 & 72.67 & 68.67 & 65.78 & 61.11 & 71.39 \\
Carrara & 78.00 & 76.44 & 64.67 & 66.44 & 73.61 \\
Gabrielle & 75.33 & 76.44 & 73.33 & 69.33 & 75.94 \\
Hm7885 & 79.11 & 81.78 & 74.44 & 68.44 & 80.61 \\
Santa Cruz Kada & 81.11 & 82.00 & 77.11 & 82.22 & 84.61 \\
Asti & 84.44 & 86.44 & 83.78 & 83.78 & 78.39 \\
N901 & 82.44 & 85.11 & 74.67 & 71.33 & 61.11 \\
Portinari & 66.22 & 63.56 & 59.11 & 55.56 & 68.94 \\
Thaise* & 71.78 & 68.22 & 71.33 & 64.44 & 79.17 \\
Dominador & 82.00 & 80.22 & 78.44 & 76.00 & 72.56 \\
Gabrielle* & 76.67 & 75.56 & 69.56 & 68.44 & 82.78 \\
Equatorial & 83.78 & 87.56 & 79.11 & 80.67 & 71.44 \\
Thaise & 76.44 & 74.67 & 68.89 & 65.78 & \\
\hline
\end{tabular}

*grown without staking.

The agreement among the consumers was lower for fruits of the cultivars Santa Cruz Kada, Asti, and Equatorial; the other cultivars showed lower agreement for the attribute flavor. The hybrids Thaise and Gabrielle (without staking) had higher agreement index for aroma; the hybrids HM7885,
N901, and Portinari had higher agreement index for color; and the hybrids Ap533, Cararra, Asti, Domindor, Equatorial, Gabrielle and Thaise (with staking), and the variety Santa Cruz Kada had higher agreement index for appearance (Figure 7). 


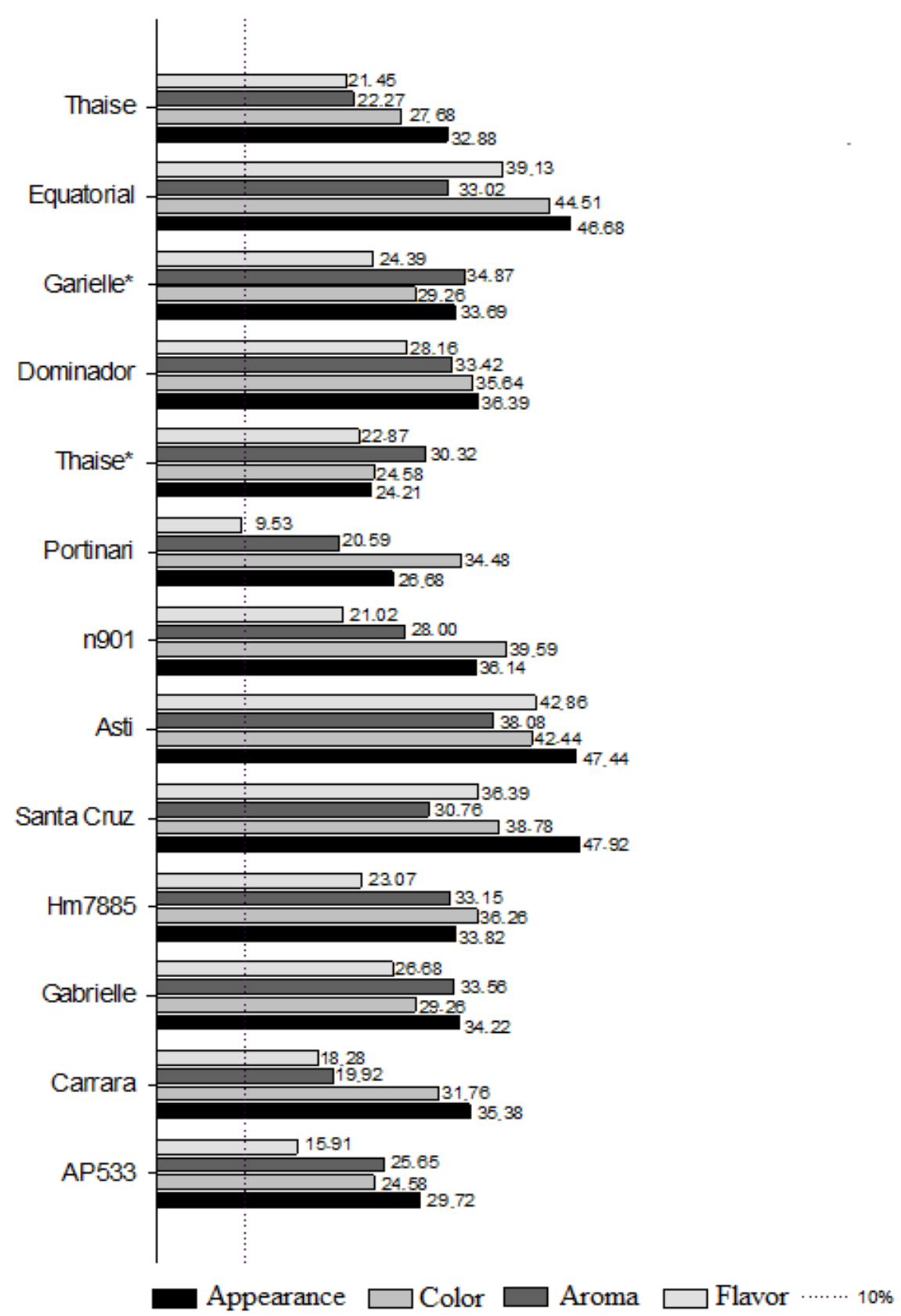

Figure 7. Agreement index (\%) among 50 consumers regarding attributes of tomato fruits. Goiânia, GO, Brazil.

The purchase intention based on the sensorial analysis showed higher purchase intention for fruits of plants of the hybrids Asti, Gabrielle (without staking), HM7885, and Equatorial, with purchase intention higher than $50 \%$; the highest rejection index was found for the hybrid Portinari, for which $40 \%$ of consumers reported that would not purchase fruits of this hybrid based on their sensorial attributes (Figure 8). 


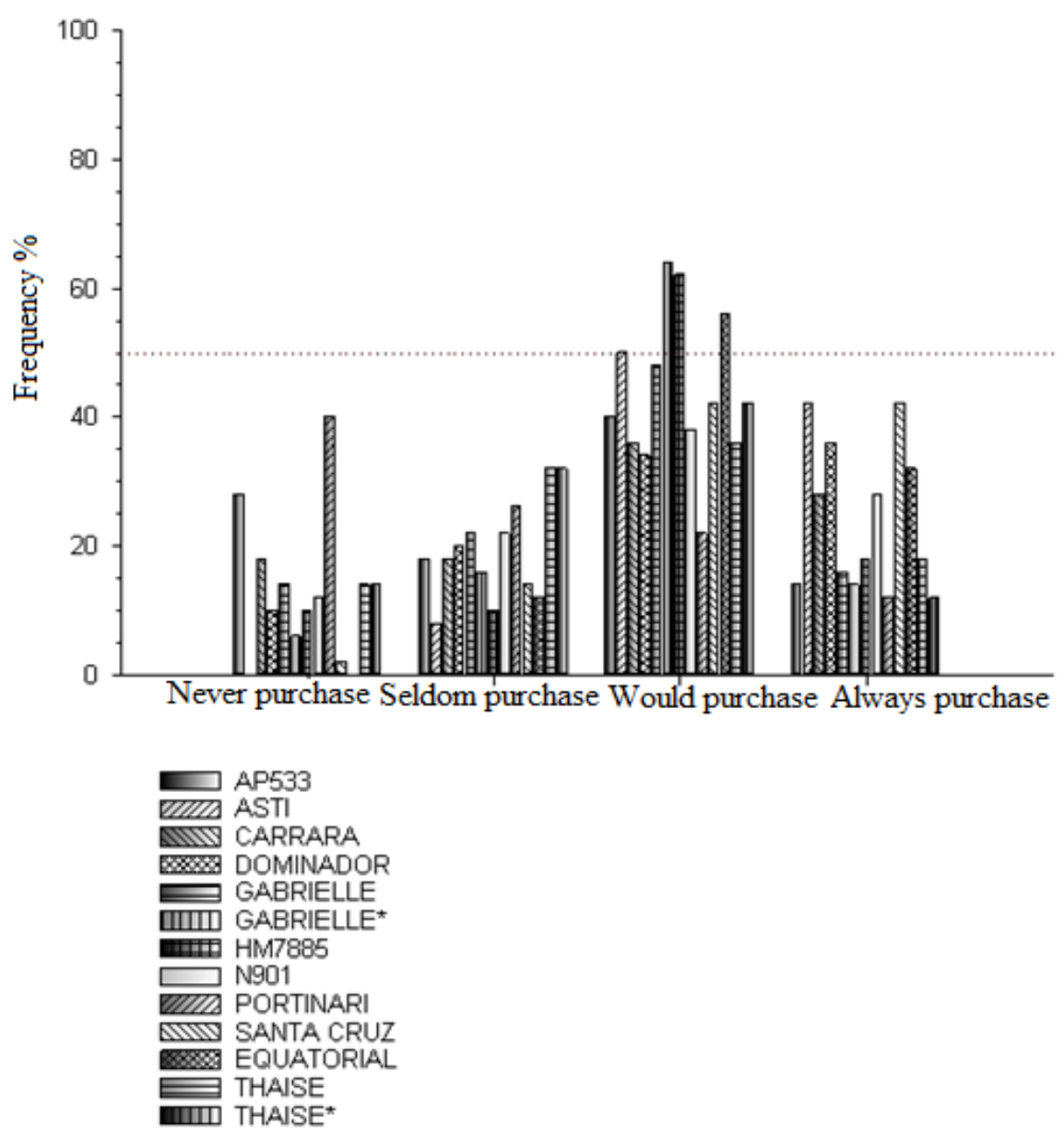

Figure 8. Purchase intention (\%) of tomato fruits by 50 not-trained consumers. Goiânia, GO, Brazil.

\section{CONCLUSIONS}

Tomato fruits from plants of the hybrids HM7885, N901, and Gabrielle grown without staking and those from plants of the hybrids Thaise and Equatorial grown with staking presented acceptability above $70 \%$, denoting that these cultivars are alternatives for tomato production for fresh consumption. Among the tomato plants with determinate growth habit, only fruits of the hybrid Ap533 presented no satisfactory results. Among the plants with indeterminate growth habit, whose fruits are already marketed for fresh consumption, only those of the hybrid Portinari presented unsatisfactory acceptability. The other hybrids (Asti, Carrara, and Dominador) and the variety Santa Cruz Kada had satisfactory acceptability for fresh consumption.

\section{REFERENCES}

ALVARENGA, M. A. R. et al. Tomate: produção em campo, casa de vegetação e hidroponia. 2. ed. Lavras: Universitária de Lavras, 2013. 413 p.
AMERICAN OF OFFICIAL ANALYTICAL CHEMISTS - AOAC. Official methods of analysis of AOAC. 19. ed. Gaitlerburg: AOAC International. 2012. $3000 \mathrm{p}$.

BORGUINI, R. G.; TORRES, E. A. F. D. Tomatoes and tomato products as dietary sources of antioxidants. Food Research International, 25: 313 $325,2009$.

BRASIL. Ministério da agricultura pecuária e abastecimento. SISLEGIS - Portaria n. 85 de 2002, Regulamento técnico de identificação e qualidade para a classificação de tomate. Disponível em: $<$ http://sistemasweb.agricultura.gov.br $>$. Acesso em: 20 jul. 2018.

BRASIL. Ministério da Saúde. SLEGIS - Resolução n. 466 de 2012, Pesquisa em seres humanos. Disponível em: <https://saudelegis.saude.gov.br>. Acesso em 20 jul. 2018.

BRASIL. Ministério da agricultura pecuária e abastecimento. SISLEGIS - Portaria n. 553 de 1995, Regulamento técnico MERCOSUL de 
identidade e Qualidade do tomate. Disponível em: $<$ http://sistemasweb.agricultura.gov.br $>$. Acesso em: 20 jul. 2018.

CALBO, A. G. Fisiologia pós-colheita em hortaliças, teórica e prática. In: FERREIRA, M. D. (Org.). Tecnologia pós-colheita em frutas e hortaliças. São Carlos, SP: Embrapa Instrumentação, 2011. v. 1, cap. 3, p. 69-92.

CHITARRA, M. I. F.; CHITARRA, A. B. Póscolheita de frutos $e$ hortaliças: fisiologia $e$ manuseio. 2. ed. Lavras, MG: UFLA, 2005. 783 p.

DELEO, J. P. B. et al. Anuário Hortifruti Brasil Retrospectiva 2019 \& Perspectiva 2020. Hortifruti Brasil, 1: 28-30, 2020.

DUTCOSKY, S. D. Análise Sensorial de Alimentos. 4. ed. Curitiba, PR: PUCPRESS, 2013. $531 \mathrm{p}$.

FOOD AND AGRICULTURE ORGANIZATION OF THE UNITED NATIONS - FAOSTAT. CROPS - Crop statistics. Disponível em: <http:// www.fao.org/faostat/en/\#data/QC $>$. Acesso em: 19 abr. 2020.

FERREIRA, S. M. R. et al. Qualidade do tomate de mesa cultivado nos sistemas convencional e orgânico, Ciência e Tecnologia de Alimentos, 30: 224-230, 2010.

INSTITUTO ADOLFO LUTZ - IAL. Métodos físico-químicos para análise de alimentos. Disponível em: <http://www.ial.sp.gov.br/ial/ publicacoes/livros/>. Acesso em: 20 jul. 2018.

INSTITUTO PARA O FORTALECIMENTO DA AGROPECUÁRIA DE GOIÁS - IFAG. Custos de produção. Disponível em: <http://ifag.org.br/custosde-producao $>$. Acesso em: 19 abri.de 2020.

KADER, A. A. et al. Composition and flavor quality of fresh quality of fresh market tomatoes as influenced by some postharvest handling procedures. Journal American Society Horticultural Science, 103: 6-13. 1978.

KADER, A. A. et al. Effect of fruit ripeness when picked on Flavor and Composition in Fresh Market Tomatoes.Journal American Society Horticultural Science, 102: 724-731, 1977.

KEMP, S. R.; HOLlOWOOD, T.; HORT, J. Sensory Evaluation: A Practical Handbook. 1. ed. West Sussex, Chichester: WILEY-BLACKWELL, 2009. $328 \mathrm{p}$.
LAWLESS, H. T.; HEYMANN, H. Sensory evaluation of food: principles and practices. 2. ed. New York: SPRINGER, 2010. 596 p.

MEILGAARD, M.; CIVILLE, G. V.; CARR, B. T. Sensory Evaluation Techniques. 5. ed. Boca Raton, FL: CRC Press, 2016. 600 p.

MORAES, M. A. C. Métodos para a avaliação sensorial dos alimentos. 7. ed. Campinas, SP: UNICAMP, $1988.93 \mathrm{p}$

MORETTI, C. L. et al. Chemical composition and physical properties of pericarp, locule, and placental tissues of tomatoes with internal bruising. Journal of the American Society for Horticultural Science, 123: 656-660, 1998.

NASSU, R. T. Análise Sensorial de Carne: Conceitos e Recomendações. 1. ed. São Carlos, SP: EMBRAPA, 2007. 7 p. (Comunicado Técnico, 79).

PERVEEN, R. et al. Tomato (Solanum lycopersicum) Carotenoids and Lycopenes Chemistry; Metabolism, Absorption, Nutrition, and Allied Health Claims A Comprehensive Review. Critical Reviews in Food Science and Nutrition, 55: 919-929, 2015

OMS-OLIUB, G. Metabolic characterization of tomato fruit during preharvest development, ripening, and posthaverst shelf-life. Postharvest Biology and Technology, 62: 7-16, 2011.

SIDDIQUI, M. W.; AYALA-ZAVALA, J. F.; DHUA, R. S. Genotypic variation in tomatoes affecting processing and antioxidant attributes. Critical Reviews in Food Science and Nutrition, 55: 1819-1835, 2015.

SOUZA, M. E. et al.Caracterização físico-química e avaliação sensorial dos frutos de bananeira. Nativa,1: 13-17, 2013. 